\title{
Estimation of Water Budget Components of the Sakarya River Basin by Using the WEAP-PGM Model
}

\author{
Salim Yaykiran ${ }^{1,2}$, Gokhan Cuceloglu ${ }^{1}$ (1) and Alpaslan Ekdal ${ }^{1, *}$ \\ 1 Environmental Engineering Department, Istanbul Technical University, Maslak, 34469 Istanbul, Turkey; \\ salim.yaykiran@suen.gov.tr (S.Y.); cuceloglu@itu.edu.tr (G.C.) \\ 2 Turkish Water Institute, Uskudar, 34696 Istanbul, Turkey \\ * Correspondence: ekdala@itu.edu.tr; Tel.: +90-212-285-6540
}

Received: 4 January 2019; Accepted: 31 January 2019; Published: 4 February 2019

\begin{abstract}
The use of water resources has increased with rapid population growth, industrial development, and agricultural activities. Besides, the problem might increase with the potential climate change impacts on water quantity. Thus, sustainable use of water resources becomes crucial. Modeling studies provide scientific support to the analysis of water resource problems and develop strategies for current and potential problems for the sustainable management of water resources. In this study, WEAP-PGM (Water Evaluation and Planning System-Plant Growth Model) was applied to the Sakarya River Basin in Turkey, where almost $50 \%$ of the area is agricultural land. The main goals in the study are compiling/integrating available data from different sources in a data-scarce region for hydrological models, and estimating the water budget components of Sakarya River Basin on an annual basis as well as investigating the applicability of WEAP-PGM. General model performance ratings indicated that model simulations represent streamflow variations at acceptable levels. Model results revealed that, runoff is 4747 million $\mathrm{m}^{3}$, flow to groundwater is 3065 million $\mathrm{m}^{3}$ and evapotranspiration is 23,011 million $\mathrm{m}^{3}$. This model setup can be used as a baseline for calculating the crop yields under climate change in the context of water-food-energy nexus in the further studies.
\end{abstract}

Keywords: hydrological modeling; WEAP; plant growth modeling; water budget; Sakarya River Basin; data integration

\section{Introduction}

Water is crucial for all living things, since it is accepted as the source of life on Earth. Therefore, the conscientious use of water resources holds high importance. The use of water resources has increased with rapid population growth, industrial development, and agricultural activities. Besides, the problem might increase with the potential climate change impacts on water quantity. Thus, the sustainable use of water resources is crucial [1,2].

Modeling studies provide scientific support to the analysis of water resource problems and develop strategies for current and potential problems for the sustainable management of water resources. Water budget components, such as surface runoff, subsurface flow, base flow, groundwater flow, evaporation, and transpiration can be calculated by using hydrological models. By developing scenarios for present and future, analyses of possible climate change impacts, population growth, land use change, crop pattern water requirement, irrigation practices can be conducted [3-8]. Various hydrological modeling studies have been carried out to determine the water budgets of watersheds [9]. Hydrological models used in these studies are WEAP (Water Evaluation and Planning System) [10-18], SWAT (Soil and Water Assessment Tool) [19-30], HYPE (Hydrological Predictions for the Environment) [31-37], MIKE SHE (Système Hydrologique Européen) [38-40], 
HEC-HMS (Hydrologic Engineering Center Hydrologic Modeling System) [41-44], SWIM (Soil and Water Integrated Model) [45-49], and HSPF (Hydrological Simulation Program-Fortran) [50-53].

In a modeling study, the developed model should be able to simulate the real system as much as possible. The data analysis step is of great importance for modeling. During the data gathering stage, the scale of the study area must be considered. Required data can be obtained from the related institutions at this phase. Local/global open access data sets can be used in cases where data at the associated institutions are inexistent [54-56]. In order to integrate data, to process numerical and spatial data and to analyze and to visualize the results numerical calculations, geographical information systems and spreadsheet programs are used [4-8].

Turkey is considered as a water stressed country, a s the yearly available water per capita is $1519 \mathrm{~m}^{3}$ [57-60]. Therefore, priority should be given to the studies conducted for protecting, developing and providing the sustainability of natural water resources. In Turkey, sustainable development of water resources is the basis for managing these resources at a watershed scale. On the other hand, in order to accomplish Water Framework Directive objectives, integrated watershed management has been accepted as the key instrument by the European Union [61,62].

In various developing/developed countries, the WEAP model has been used widely, whereas the use of the model in the studies conducted in Turkey is limited. Cuceloglu \& Ertürk [12] conducted a hydrological modeling study in Darlık Basin with the WEAP model, and calculated the water budget components of the study area. Surface flow, base flow, percolation, groundwater flow and daily evaporation of the basin were determined. A model infrastructure has been established in which the effects of population growth, land use change and global warming on the current and future water budget components can be estimated. Yilmaz \& Harmancioğlu [14] developed a watershed management model that examines the environmental, social and economic situation of Gediz Basin. In the study, researchers aimed to simulate and evaluate possible management strategies based on measured indicators using WEAP. Yilmaz [15] studied the climate change impacts on water balance of the Gediz Basin with the WEAP model with the aim of examining the supply-demand balance and the unmet demand areas with regional and global climate models. The model was operated at 30-year intervals until 2100, and the possible climate change impacts on the basin were simulated; evaluations and recommendations were made.

The Plant Growth Model (PGM) method was added to the WEAP model in 2015 and is being updated with new versions [63]. This study is one of the pioneer studies in the world and Turkey that used WEAP-PGM after its release. The model was applied to the Sakarya River Basin in Turkey, where almost $50 \%$ of the area is agricultural land. Agricultural irrigation has the highest water demand in Turkey between the sectors for annual water consumption with $74 \%$ share. As agricultural activities are of utmost importance for water resource management, it was considered that a plant-based model would better simulate the hydrological behavior of the basin. This study is expected to form the base model for investigating future climate change impacts on water resources and crop yield in the basin. There are numerous hydrological models available, but few of them have a crop growth module. In recent years, watershed models having crop growth modules, such as SWAT and EPIC (Environmental Policy Integrated Climate Model), have been used in many studies. This research aimed to investigate the applicability of the WEAP model with its recently developed module. WEAP also allows users to model human activities' impact on the hydrological cycle, such as water transfers, irrigation, dam operations, etc. easily with its user-friendly interface. Therefore, WEAP-PGM was chosen as the model for the Sakarya River Basin among other watershed models.

The main goals of this study are compiling/integrating available data from different sources in a data-scarce region for hydrological models, and estimating the water budget components of the Sakarya River Basin at annual basis by using the WEAP model. This study is one of the first attempts to investigate the applicability of the WEAP-PGM in hydrological simulations, as stated in the previous paragraph. In this paper, results obtained from the application of the model to the selected area are presented and discussed along with its model setup. 


\section{Materials and Methods}

\subsection{WEAP Model}

Stockholm Environmental Institute (SEI) developed the WEAP (Water Assessment and Planning System) model, which is a user-friendly software to plan water resources' use with an integrated approach. This model can be used for modeling natural and artificial components of the system such as streamflow, base flow, groundwater potential, sectoral water demand, water allocation priorities, reservoir operations, hydroelectric power generation, financial planning, water quality, and environmental requirements. The effects of climate change on water resources can be investigated according to various climate and water allocation scenarios [10]. More details and equations can be found in the WEAP User Guide [64]. Various hydrological processes (infiltration, runoff, evapotranspiration) and water demand (environmental flow, irrigation, domestic uses etc.) can be simulated with five different approaches. The approaches used in the model are as follows:

- Rainfall Runoff

- Irrigation Demands Only versions of the Simplified Coefficient Approach

- Soil Moisture Method

- The MABIA Method

- Plant Growth Model

In the study, the plant growth model (WEAP-PGM) has been selected, since its structure is appropriate for water management studies; besides, hydrological processes in the model take into consideration varying atmospheric $\mathrm{CO}_{2}$ level and temperature effects on plant water use and growth. Thus, the model is capable of analyzing the climate change impacts on crop growth and its water demand. The plant growth routines are based on an approach used by SWAT [65] and EPIC [66-68] model databases. Calculation of water consumption for agricultural production and demand for irrigation can be done; thus, analysis of crop pattern effects on the hydrology of catchment can be conducted. Illustration of the basic structure of the WEAP-PGM model is compiled by using the schematics provided in $[63,69]$ (Figure 1).

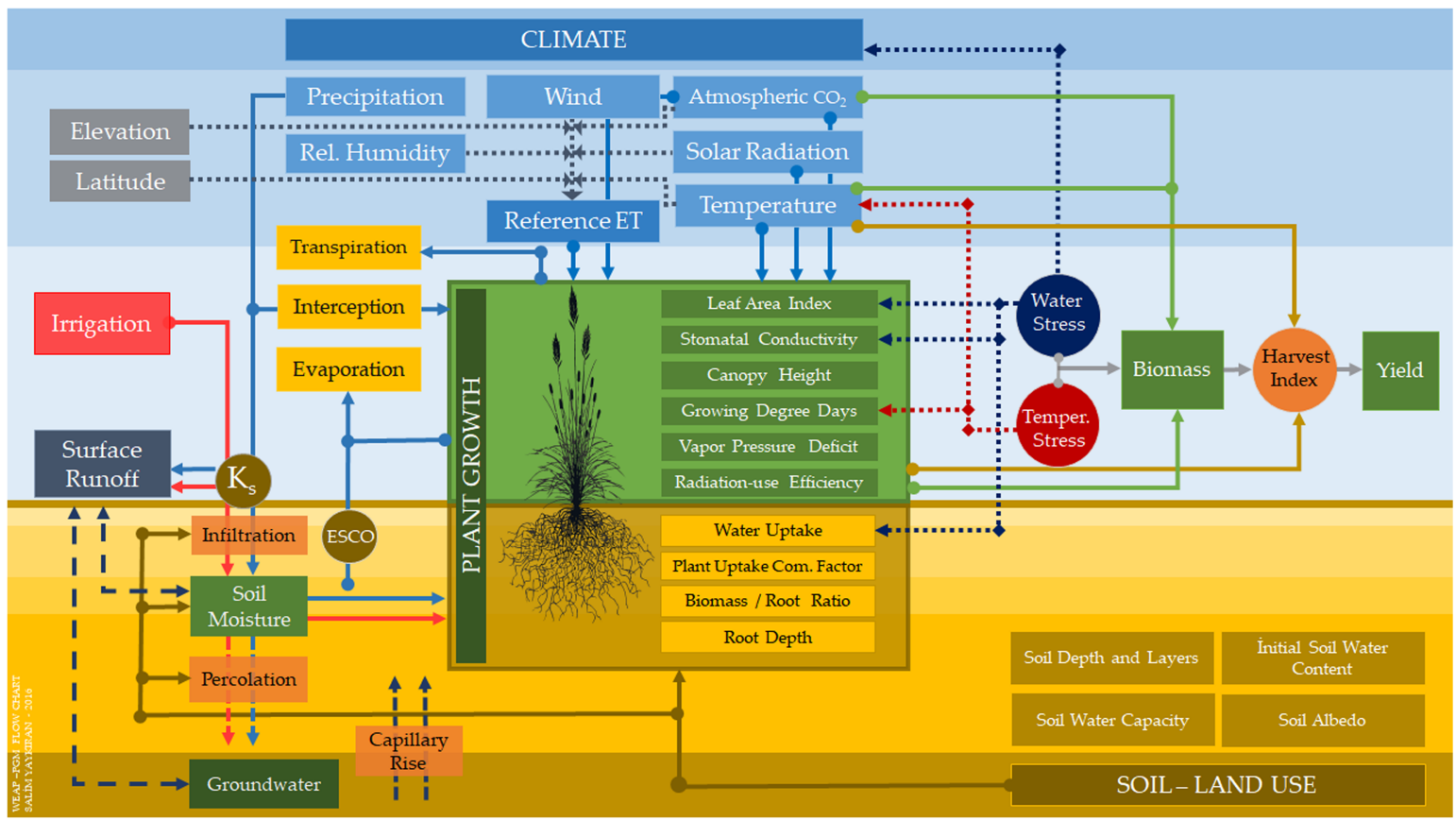

Figure 1. The structure of the conceptual WEAP Plant Growth Model. 


\subsection{Study Area}

The Sakarya River Basin, which is located in the northwest Anatolian region of Turkey, was chosen as the study area (Figure 2). The drainage area of Sakarya River that discharges into Black Sea is $58,160 \mathrm{~km}^{2}$, and it covers about $7 \%$ of Turkey. The average altitude of the basin is $965 \mathrm{~m}$. Due to its location and wide coverage, various climatic characteristics are observed in the basin; however, the typical continental climate is the dominant one. The average temperature is between $3{ }^{\circ} \mathrm{C}$ and $13{ }^{\circ} \mathrm{C}$ in winter, and between $24^{\circ} \mathrm{C}$ and $32{ }^{\circ} \mathrm{C}$ in the summers. Long-term average annual precipitation in the basin is approximately $480 \mathrm{~mm}$, which is lower than the average of Turkey, and increases from south to north generally. The average total annual rainfall in the Sakarya River Basin was estimated as 32 billion $\mathrm{m}^{3}$. It contributes to $3.4 \%$ of Turkey's water potential with an average annual flow of 6.4 billion $\mathrm{m}^{3}$ [70-72].

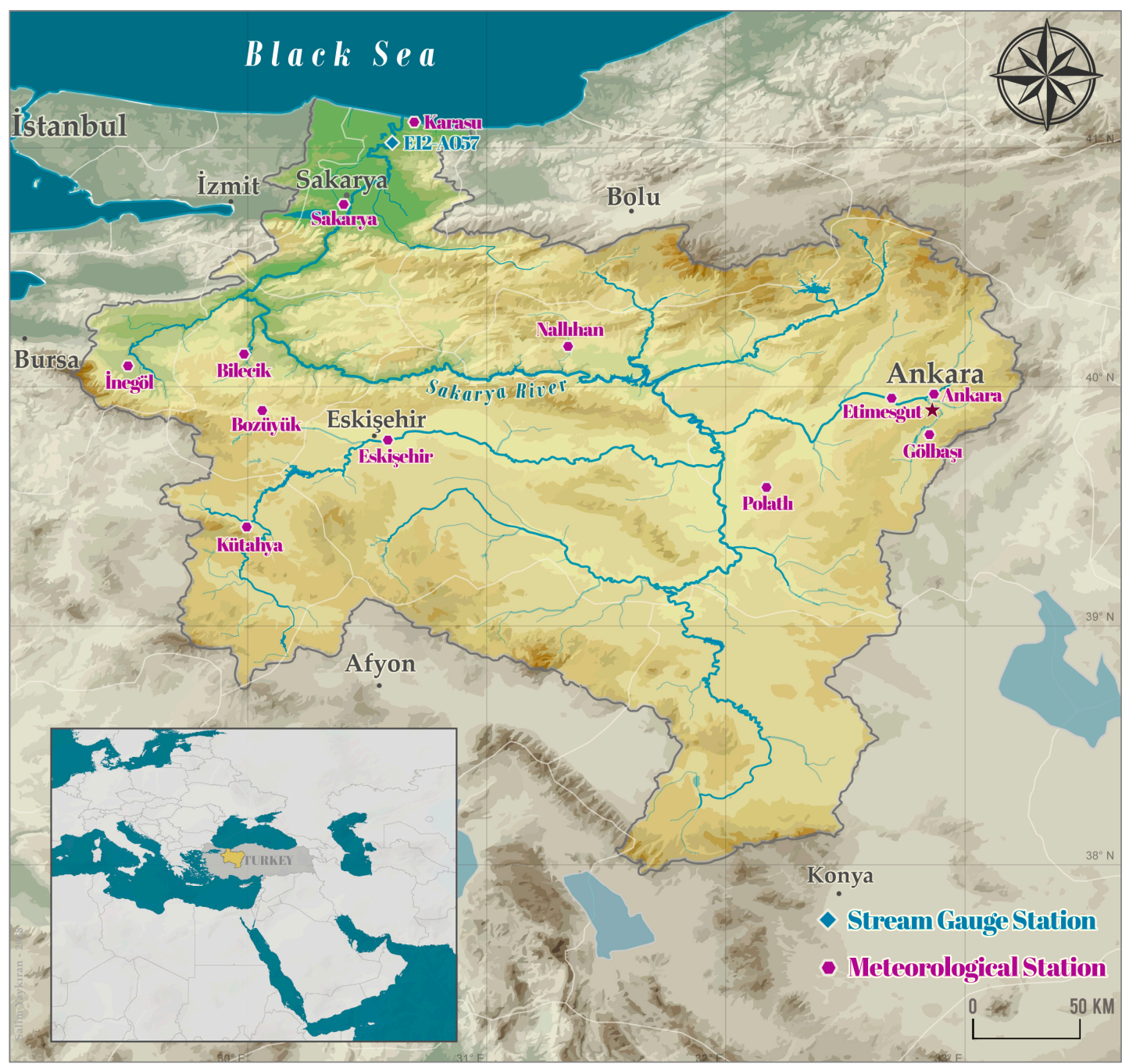

Figure 2. Sakarya River Basin.

The city center of Ankara, which is the capital of Turkey, is located within the basin. The Sakarya River Basin also neighbors the water resources of mega city Istanbul, which has more than 15 million inhabitants. Due to its location, the Sakarya River Basin is of utmost importance for interbasin water transfers, economy and cultural activities, as well as transportation. The Sakarya River Basin hosts approximately one-tenth of Turkey's population, and Ankara has the largest population within the basin [70]. According to the Falkenmark water stress index, the Sakarya River Basin can be considered as a region that has water shortage, since the amount of annual available water changes between 
1000-1700 $\mathrm{m}^{3}$ per capita. Water scarcity is anticipated to be experienced in the near future because of an increasing population and climate change impacts in the basin [58-60].

\subsection{Data Analysis and Model Setup}

Structuring a high-resolution hydrological model for the Sakarya River Basin is required for achieving the main objectives of this study. The WEAP-PGM model requires topography, land use, crop pattern, soil and climate data. In order to build a model and analyze the model results, required data for this study were obtained and compiled from national, global and local datasets (Table 1, Figure 3).

Table 1. Data type, source, and resolution used in this study.

\begin{tabular}{lll}
\hline Data Type & Source & Resolution \\
\hline Topography & $\begin{array}{l}\text { SRTM (Shuttle Radar Top. Mission) Digital } \\
\text { Elevation Map [73] }\end{array}$ & $30 \mathrm{~m}$ \\
\hline Land use & CORINE 2012 Land Cover Project [74] & $100 \mathrm{~m}$ \\
\hline \multirow{2}{*}{ Soil } & Turkish National Soil Database [75] & $1: 25,000$ \\
\cline { 2 - 3 } & ISRIC Soil Grid 1 km Project [76] & $1 \mathrm{~km}$ \\
\hline Crop pattern & TSI Crop Production Statistics Database [77] & District Level \\
\cline { 2 - 3 } & Turkish National Stand Type Maps [78] & $1: 25,000$ \\
\hline Climate & Turkish National Climate Reports [79] & 14 Stations \\
\hline River discharge & Turkish National River Discharges Reports [80] & 1 Station \\
\hline
\end{tabular}
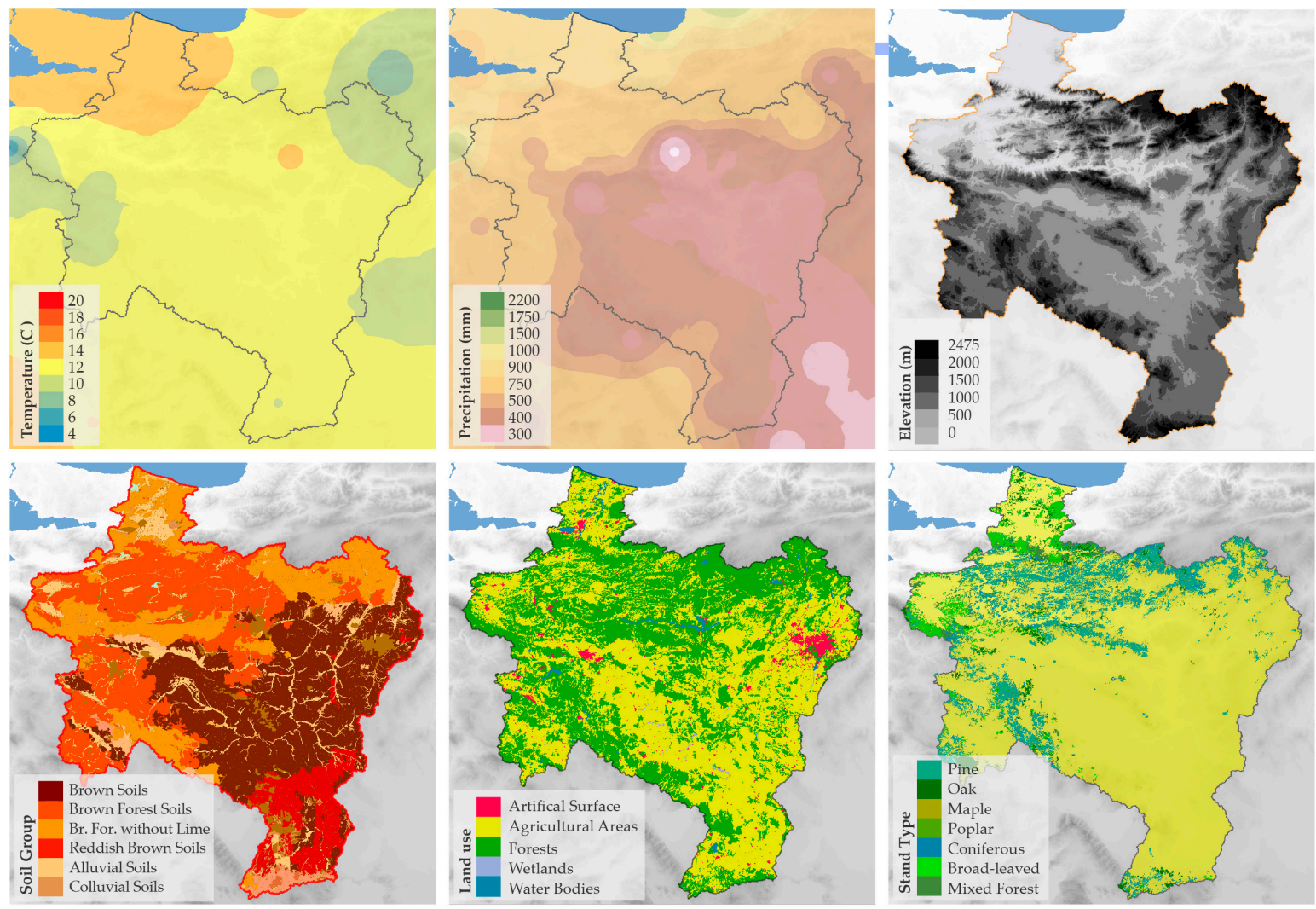

Figure 3. Maps of the study area; temperature, precipitation, elevation, soil group, land use, and stand type. 
DEM (Digital elevation map) derived from SRTM (Shuttle Radar Topography Mission) with a resolution of 1 arc-second $(30 \mathrm{~m} \times 30 \mathrm{~m})$ data were used to delineate the drainage areas with ArcSWAT [81,82] software (version 2012.10-3.18, Texas A\&M AgriLife Research, College Station, TX, USA), and the basin was divided into 379 sub-basins.

Provincial-level National Soil Database with 1:25,000 scale was collected from former Ministry of Food, Agriculture and Livestock of the Republic of Turkey. ISRIC (International Soil Reference and Information Centre) soil data set produced in Soil Grid $1 \mathrm{~km}$ Project were obtained from its website. Total of 30 raster data were created, which include the average silt and sand percentage, bulk density $\left(\mathrm{kg} / \mathrm{m}^{3}\right)$, soil organic carbon content, and coarse fragment (volumetric, \%) properties for six layers for each Great Soil Group-Depth Combination. Raster data were overlapped with Great Soil Group-Depth Combination areas of the national database and average values were obtained for each of them. Average pixel values of ISRIC data were calculated related to each spatial area of Great Soil Group-Depth Combination elements. Then, analysis for determining the physical and hydraulic characteristics of soil were carried out for each combination group. In order to consider soil-water relations, pedotransfer functions were used [83]. In this study, National Soil Database and ISRIC soil maps were combined for generating a new soil map aiming at both increasing spatial representation and maintaining the soil classification and soil characteristics.

TSI (Turkish Statistics Institute) Crop Production Database and EPA (European Environment Agency) CORINE (Coordination of Information on the Environment) Land Cover Project (Level 3) spatial data were combined for classifying the spatial distribution of land use, crop pattern and planted land. In order to achieve this purpose, publicly available national and global database, which can be accessed through the internet, were used. At the end of this process, spatial attributes were included to TSI database. Distribution of crops in an agricultural area can be calculated with the integration of these databases. For example, it is possible to say that the agricultural land consists of $70 \%$ wheat, $10 \%$ barley and $20 \%$ corn rather than just classifying as "agricultural land". In the study, integration of SWAT crop parameters with WEAP-PGM crop library was also done. This allowed defining the planting and harvesting dates for field crops. The flowchart of data analyses process applied in the study is given in Figure 4.

In this study, an alternative approach has been proposed for Turkey for the analysis of crop pattern within hydrological studies, which can be used in different regions with site-specific datasets. According to the results of the CORINE-TSI data integration, the distribution of agricultural land in the basin for 2015 was calculated as: $76 \%, 22 \%$ and 3\% for non-irrigated agriculture, irrigated agriculture and orchard, respectively. The highest share belongs to wheat with $32 \%$ in non-irrigated agriculture; on the other hand, the second one is barley with $14.4 \%$ share, and fallowed agricultural land has a $24.3 \%$ share. In irrigated agriculture, crops such as sunflower, beet, chickpea, etc. have a high share, as given in Figure 5.

However, the developed approach mentioned above was applied for the year 2015; due to the available data, it can also be applied to other years in the simulation period, and their crop pattern could be identified and compared. Stand type data was integrated with land use map (CORINE) and results were analyzed. The stand type distribution results obtained for pine, oak, maple and poplar trees covers $74.58 \%, 14.92 \%, 10.26 \%, 0.23 \%$ of the study area, respectively. Artificial water moves in the basin such as irrigation and hydraulic structures as well as water transfers were introduced into the model. For example, water is transferred from one province to the other within the basin boundaries depending on their water demand and water resources availability. Furthermore, irrigation data were available on an annual basis; in order to supply monthly data, the total annual consumption was distributed between the months when irrigation is conducted. The monthly variations were defined as 10\% for February and July, and 20\% for March, April, May and June, of the total annual consumption. It was assumed that irrigation is conducted when the soil moisture is less than $50 \%$. Irrigation implementation can transport the water from its source to an agricultural land in a farther location, so it has an importance in the water movement. 


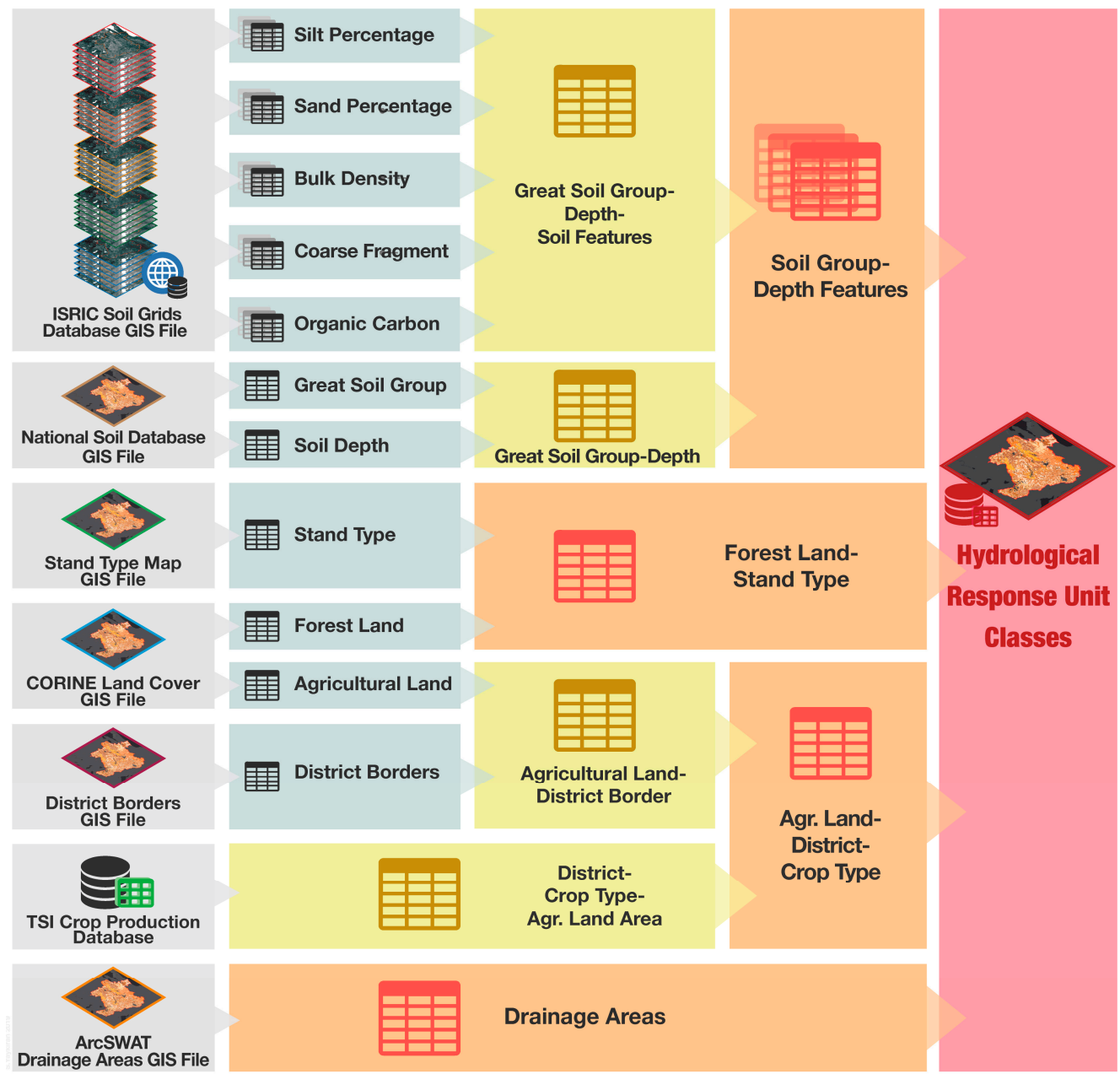

Figure 4. The flowchart of data analyses process.

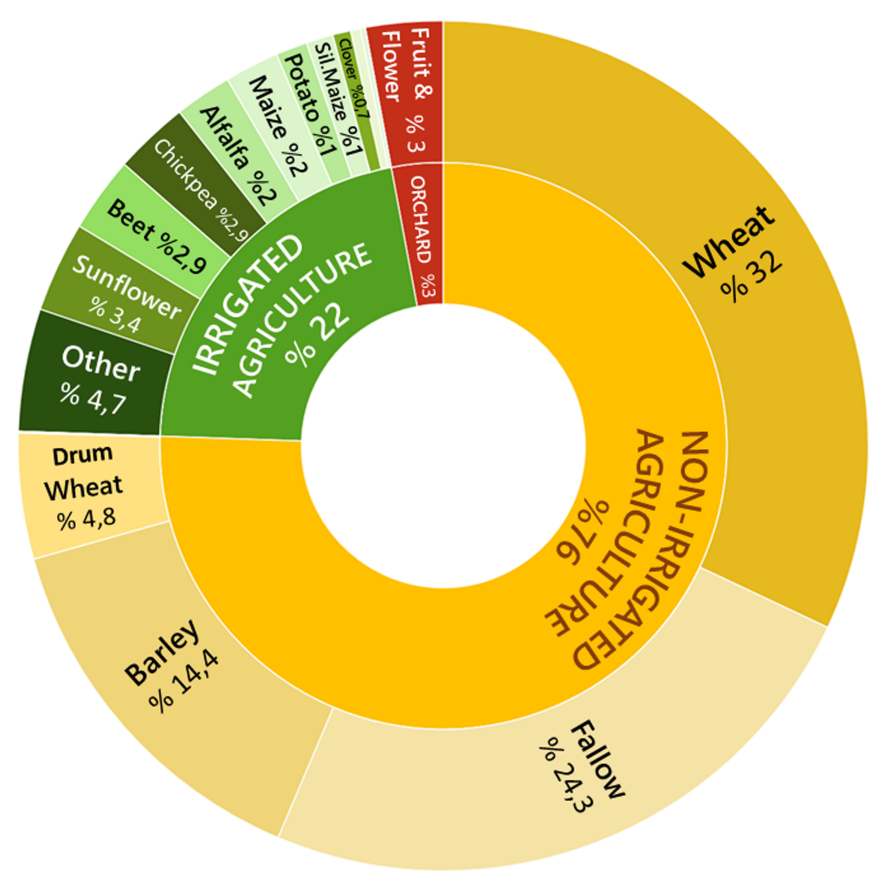

Figure 5. Agricultural land and crop pattern distribution in 2015 for the Sakarya River Basin. 
In order to determine the Hydrological Response Units (HRUs) for the study area (Figure 6); land use, crop pattern and soil characteristics were compiled by using ArcMap, MS Excel, and MATLAB (Matrix Laboratory) programs. At the end, the number of HRUs defined for the basin was 4150. Representation of the Sakarya River Basin's WEAP-PGM modules is shown in Figure 7.

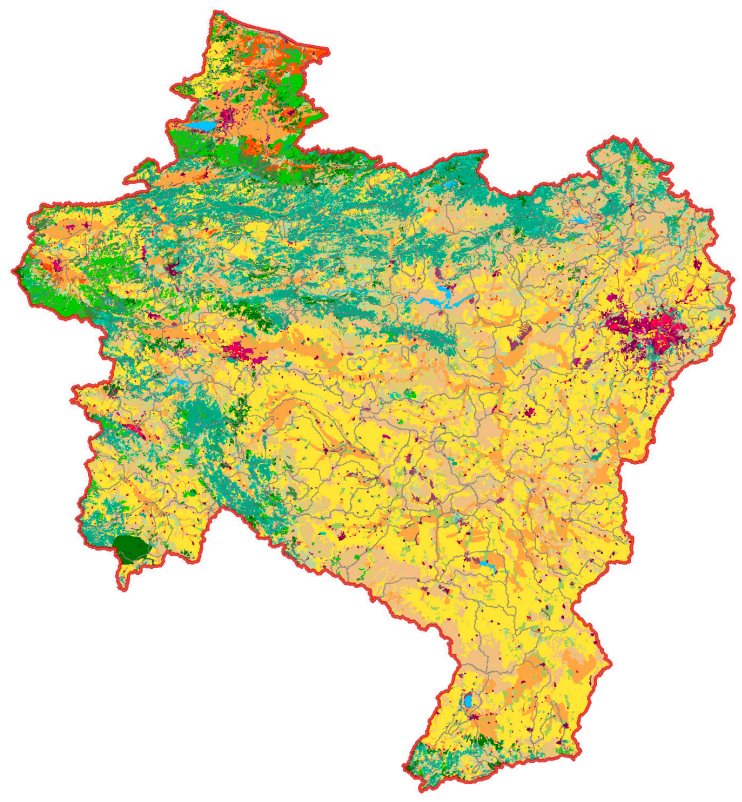

\section{HRU Classes}

\begin{tabular}{|c|c|c|}
\hline Non Irrigated Agr. & AGRC & Non Irrigated Ag. Sub-Cle \\
\hline Irrigated Agr & AGRR & - Close-Grown \\
\hline Orchard & ORCD & eat WWH \\
\hline Maple & MAPL & - Barley \\
\hline Pine & PINE & - Oats \\
\hline Poplar & POPL & - Cow Vetches \\
\hline Oak & OAK & FALC \\
\hline Forest-Deciduous & FRSD & Irrigated Ag. Sub-Cla \\
\hline Forest-Evergreen & FRSE & - Alfalfa \\
\hline Forest-Generic & FRST & - Corn (Maize) \\
\hline Agricul. \& Natural Veg. & AGRL & $\begin{array}{l}\text { - Corn Silage } \\
\text { - Sunflower }\end{array}$ \\
\hline Pasture & PAST & - Peas \\
\hline Range-Brush & RNGB & - Potato \\
\hline Range-Grasses & RNGE & - Sugar Beets \\
\hline Continuous Urban & 111 & - Ag/CornS. \\
\hline Discontinuous Urban & 112 & \\
\hline I Indust.,Comm.,Transp. & 120 & \\
\hline Artificial, Non-Agricult. & 140 & \\
\hline Water Bodies & 500 & \\
\hline
\end{tabular}

Figure 6. Hydrological Response Unit classes in the Sakarya River Basin.

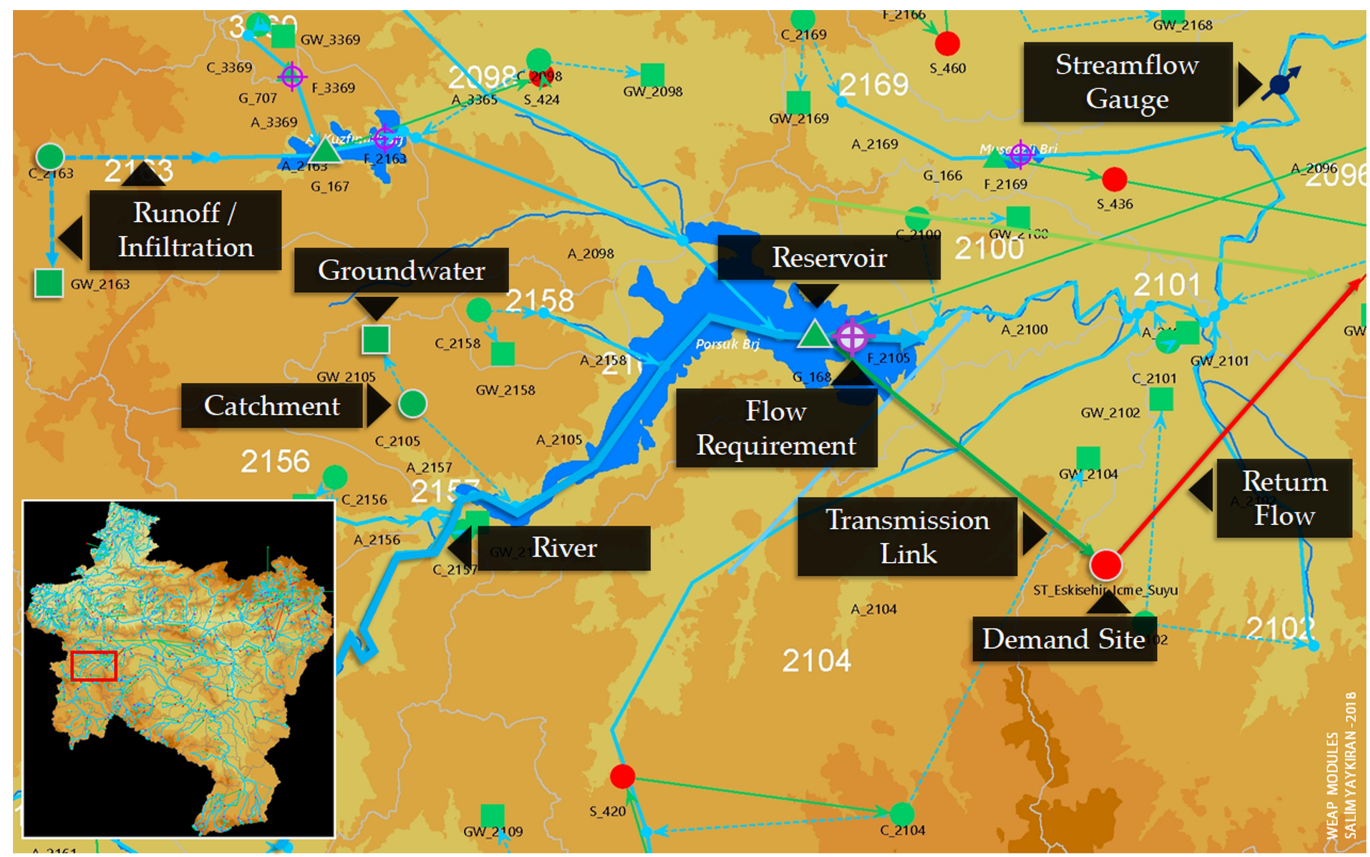

Figure 7. Representation of the Sakarya River Basin's WEAP-PGM modules.

When all required data were compiled and integrated, the hydrological model was run. Hydrological model simulations were conducted between 2003-2011, and the model results were evaluated with the data obtained at the gauge station located at the outlet of the basin (Figure 2). The data belonging to 2003-2007 were used for calibration, and the remaining data were used for validation. In this study, the WEAP-PGM model was manually calibrated by monthly discharge data. The coefficient of determination $\left(\mathrm{R}^{2}\right)$, Nash-Sutcliffe Efficiency (NSE) [84], Kling-Gupta Efficiency 
(KGE) [85], percent bias (PBIAS) and observations standard deviation ratio (RSR) methods were used as benchmarking indices to evaluate the model's performance.

$\mathrm{R}^{2}$ defines goodness of fit of the regression line by using the ratio of the sum of squares of regression to the sum of squares of values around the average. As $R^{2}$, becomes closer to 1 , the goodness of fit increases. Generally, greater than 0.5 values are considered acceptable. Coefficient of determination was calculated as given by Equation (1), where $Q_{o b s}$ represents observed flow rates, $Q_{\text {sim }}$ flow rate model results and $\bar{Q}$ average flow rate values.

$$
\mathrm{R}^{2}=\frac{\sum\left[\left(Q_{s i m}-\bar{Q}_{s i m}\right)\left(Q_{o b s}-\bar{Q}_{o b s}\right)\right]^{2}}{\sum\left(Q_{s i m}-\bar{Q}_{s i m}\right)^{2} \sum\left(Q_{o b s}-\bar{Q}_{o b s}\right)^{2}}
$$

NSE is commonly used for measuring the goodness of fit in hydrological modeling. It defines the relative magnitude of the residual variance (noise) compared to the observed data variance. The NSE combines the correlation of observed and simulated data, and also averages and standard deviations, which is calculated as given by Equation (2). The NSE coefficient ranges between $-\infty$ and 1.0. Values of NSE is between 0.0 and 1.0 indicates that the performance of the method is at an acceptable level. However, if it is lower than 0 , it indicates that the simulated value is worse than the mean observed value, so model performance cannot be accepted $[84,86]$.

$$
\mathrm{NSE}=1-\frac{\sum\left(Q_{o b s}-Q_{\text {sim }}\right)^{2}}{\sum\left(Q_{o b s}-\bar{Q}_{o b s}\right)^{2}}
$$

KGE is formulated by separating NSE into various components. It is reproduced by temporal dynamics $(r)$ while maintaining the distribution of flows $(\alpha, \beta)$. The KGE is calculated as given in Equations (3) and (4), where $r, \alpha$ and $\beta$ indicate the mean, the standard deviation, and the correlation between data and observation, respectively. Value of KGE can change between $-\infty$ and 1.0. If the value of KGE is between 0 and 1, it indicates that the performance of the method is at an acceptable level [87].

$$
\begin{gathered}
\mathrm{KGE}=1-\sqrt{(r-1)^{2}+(\alpha-1)^{2}+(\beta-1)^{2}} \\
\alpha=\frac{\sigma_{\text {sim }}}{\sigma_{o b s}}, \quad \beta=\frac{\mu_{\text {sim }}}{\mu_{o b s}}
\end{gathered}
$$

PBIAS evaluates the average trend of simulated values to be larger or smaller than observed values, and is calculated as given by Equation (5). PBIAS can vary in different small and large ranges with negative and positive. The optimal value is 0.0 , and values close to zero indicate a better model performance. PBIAS values greater than 0 indicate overestimation, whereas the ones lower than zero show that the model underestimates the results [88].

$$
\text { PBIAS }=\left[\frac{\sum\left(Q_{\text {sim }}-Q_{o b s}\right)}{\sum Q_{o b s}}\right] \times 100
$$

RSR standardizes root mean square error (RMSE) using the standard deviation of the observed data. The RSR is calculated as given by Equation (6). RSR efficiency ranges from 0.0 (the best fit) to large positive values. The higher RSR means higher RMSE, which indicates poor model performance [89].

$$
\mathrm{RSR}=\frac{\sqrt{\sum\left(Q_{o b s}-Q_{s i m}\right)^{2}}}{\sqrt{\sum\left(Q_{o b s}-\bar{Q}_{s i m}\right)^{2}}}
$$




\section{Results and Discussion}

\subsection{Flow Rate Results}

Monthly calibration and validation results of the model simulations on an anual basis are summarized in Table 2, and the general performance ratings are given in Table 3. Satisfactory model results for a monthly streamflow were obtained for both NSE and RSR values. However, there are some poor model performances on a monthly basis, but quite good model performance was achieved for PBIAS according to Moriasi et al. [89]. In the general model performance ratings, the NSE and PBIAS values are at the acceptable level, which is compatible with the objectives of the study, as can be seen from Table 3 .

Table 2. Model performance rating results on annual basis.

\begin{tabular}{lccccccccc}
\hline \multirow{2}{*}{$\begin{array}{l}\text { Benchmarking } \\
\text { Indices }\end{array}$} & \multicolumn{3}{c}{ Calibration Period } & \multicolumn{5}{c}{ Validation Period } \\
\cline { 2 - 10 } & $\mathbf{2 0 0 3}$ & $\mathbf{2 0 0 4}$ & $\mathbf{2 0 0 5}$ & $\mathbf{2 0 0 6}$ & $\mathbf{2 0 0 7}$ & $\mathbf{2 0 0 8}$ & $\mathbf{2 0 0 9}$ & $\mathbf{2 0 1 0}$ & $\mathbf{2 0 1 1}$ \\
\hline $\mathbf{R}^{\mathbf{2}}$ & 0.89 & 0.59 & 0.75 & 0.80 & 0.83 & 0.84 & 0.81 & 0.55 & 0.65 \\
NSE & 0.74 & 0.39 & 0.22 & 0.65 & -0.27 & -1.16 & 0.76 & 0.48 & 0.39 \\
KGE & 0.78 & 0.53 & 0.40 & 0.54 & 0.19 & -0.11 & 0.68 & 0.63 & 0.67 \\
PBIAS & 21.68 & -30.08 & 7.26 & -21.8 & -31.68 & 46.23 & -9.32 & -18.31 & -12.58 \\
RSR & 0.51 & 0.78 & 0.88 & 0.59 & 1.13 & 1.47 & 0.49 & 0.72 & 0.78 \\
\hline
\end{tabular}

Table 3. General model performance ratings.

\begin{tabular}{lccc}
\hline Benchmarking Indices & Calibration & Validation & Simulation Period \\
\hline $\mathbf{R}^{2}$ & 0.57 & 0.56 & 0.55 \\
NSE & 0.55 & 0.54 & 0.53 \\
KGE & 0.73 & 0.59 & 0.72 \\
PBIAS & -9.15 & 1.09 & -3.60 \\
RSR & 0.67 & 0.70 & 0.69 \\
\hline
\end{tabular}

$\mathrm{R}^{2}$ values for both periods range from 0.55 to 0.89 , so that model simulations represent the streamflow variations at acceptable levels. Duru et al [29] conducted a study in the Ankara River Basin, which has a drainage area of $4932 \mathrm{~km}^{2}$, for predicting the stream flow and sediment yield with SWAT model between 1989-1996. According to their results, the NSE value was calculated as 0.79 on monthly basis for their simulation period. A similar study was conducted by Güngör and Göncü [22] in Lower Porsuk River Basin $\left(5649 \mathrm{~km}^{2}\right)$ on a monthly basis to estimate the streamflow by using the SWAT model. They calibrated the model at two gauge stations, their model performance for the NSE value were 0.74 and 0.59 for the calibration period, and 0.87 and 0.31 for the validation period, respectively. Both studies were conducted in the sub-basins of the Sakarya River Basin. Although these studies were faced with similar data problems, they achieved acceptable model performance satisfying their objectives [22,29]. These model performances were acceptable for these sub-basins, but it should be kept in mind that achieving higher model performances can be difficult for the entire Sakarya River Basin, since the impact of the data limitation is higher at a larger basin scale. So, the model performance ratings of our study satisfy the objectives, considering the available data and inadequate representation of anthropogenic activities to the model in the entire Sakarya River Basin. The model results are relatively not satisfactory for 2004-2005 and 2007-2008. One of the reasons for the poor performance of the model over these years could be the effect of water transfers from other basins and changes in the reservoir operations due to the drought that occurred in the region. The drought observed in the 2007-2008 period was more intense; since, it was observed not only in the study area but also throughout Turkey. During this extreme period in the basin, temporal changes in the water consumption rates by agricultural demand cannot be represented in the model at a satisfactory level (Figure 8). 

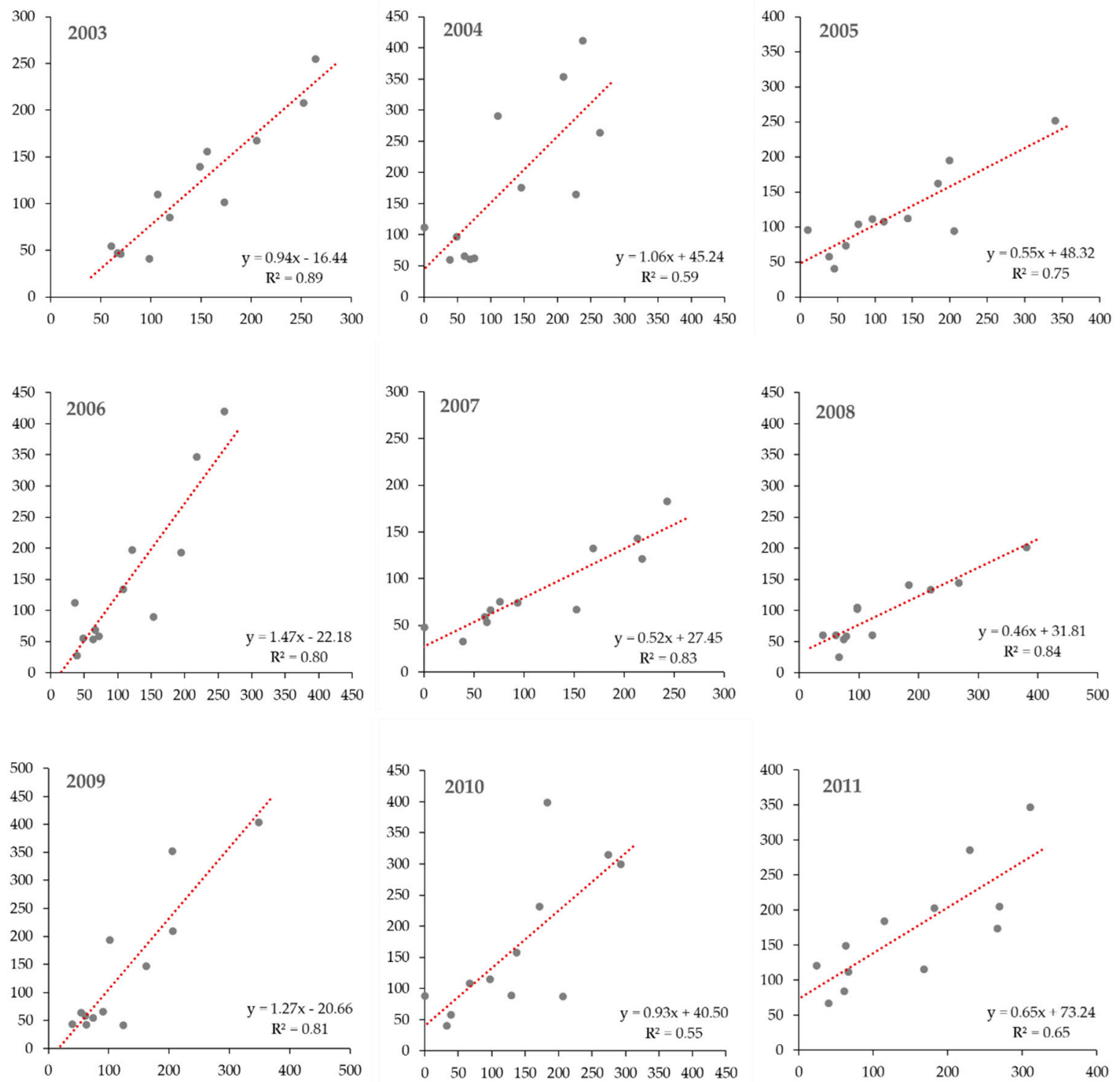

Figure 8. Regression of simulated and observed annual discharges for the basin outlet. The y-axis shows the observed data, whereas the x-axis shows model simulations. Both axes are in the unit of $\mathrm{m}^{3} \cdot \mathrm{s}^{-1}$.

Monthly observed and simulated flowrate time series at the outlet of the Sakarya River Basin as well as the monthly precipitation rates are given in Figure 9. As discussed previously, the main focus of the study is estimating the annual water budget; thus, monthly results represent the watershed dynamics at a satisfactory level. Discrepancies in monthly results might be due to missing reservoir operations data, and lack of routing components in the model. Routing processes are quite important to simulate the hydrograph shifts in basins with high concentration times [90,91], as is the case of the Sakarya River Basin. Uncertainty of water consumption rates from wells for agricultural activities and inadequate groundwater data availability affect simulation performance of the baseflow (Figure 9). The long-term monthly average of observed and simulated flowrates, and comparison of annual observed and simulated discharges are depicted in Figure 10. 


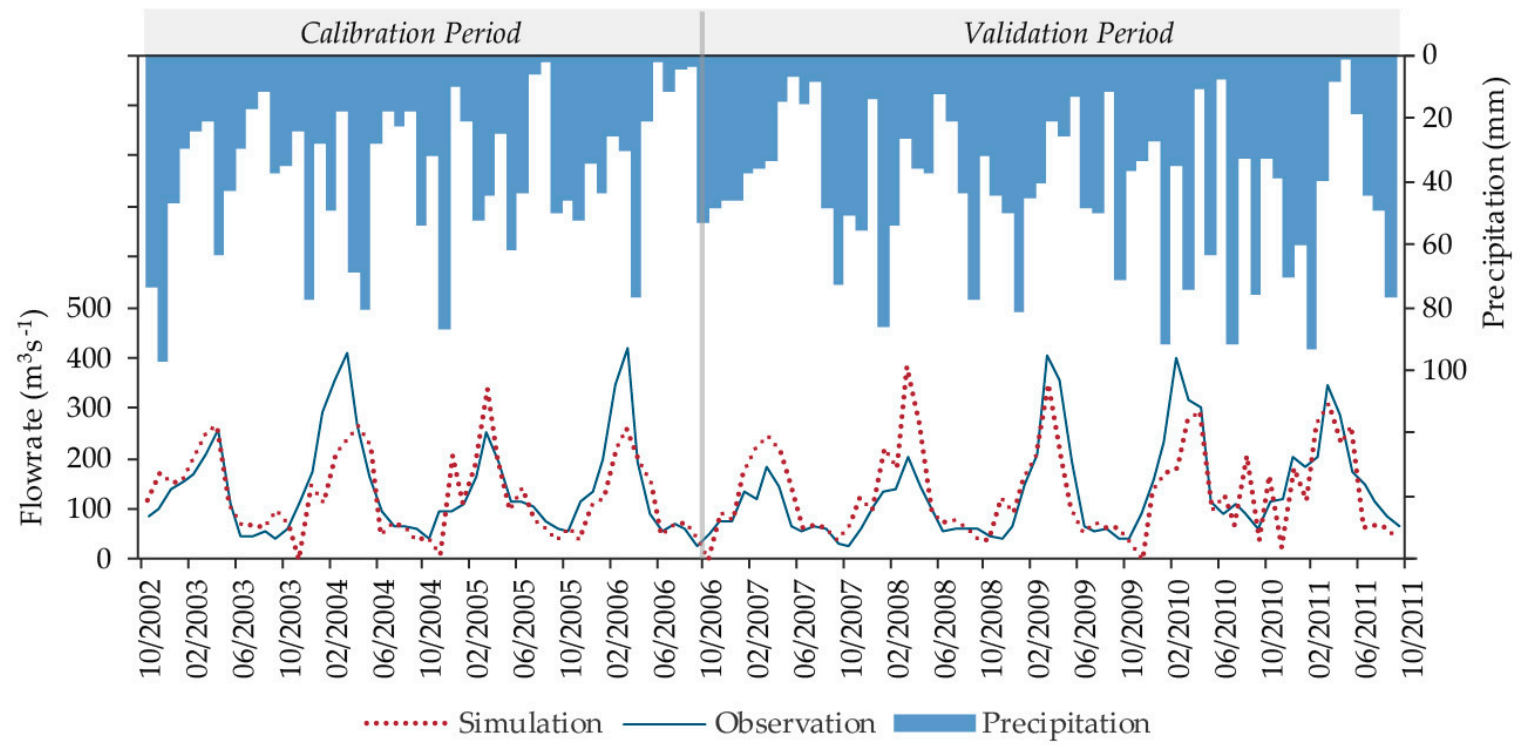

Figure 9. Monthly observed and simulated flowrate time series.

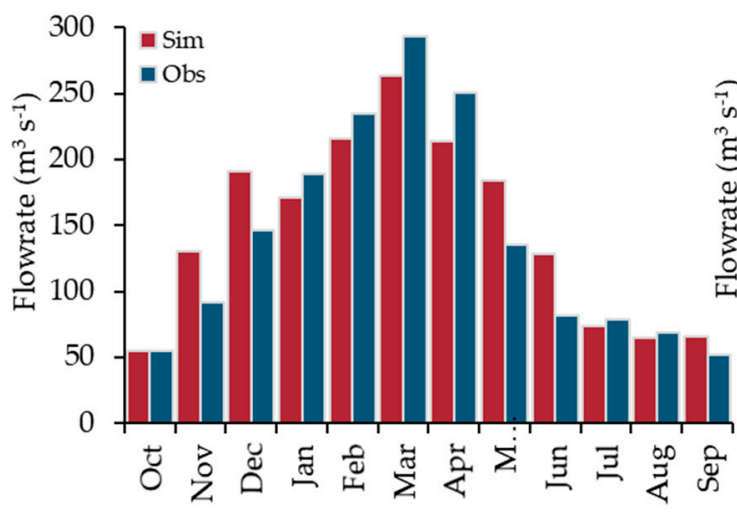

(a)

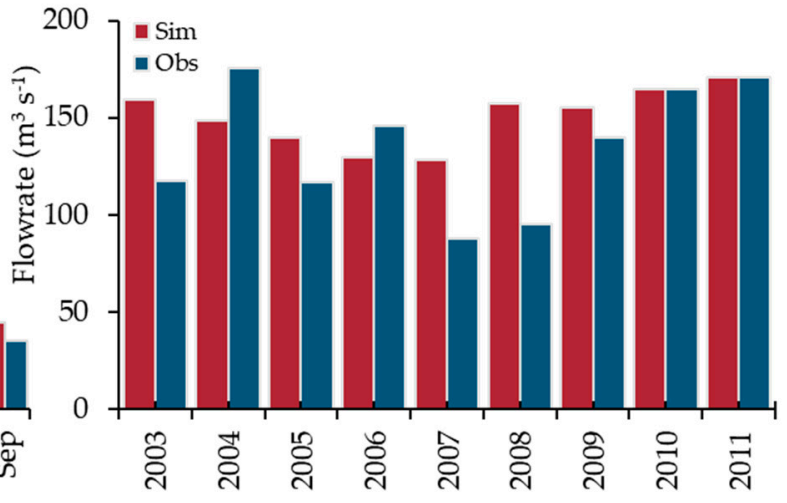

(b)

Figure 10. Comparison of: (a) Long-term monthly average of observed and simulated flowrates; (b) annual observed and simulated flowrates.

\subsection{Water Budget}

The principle of conservation of mass is the basis of the water budget equation, and it takes into account all flows entering and leaving the system, and the amount of stored water in the system at a certain time interval. The estimated annual water budget components of the Sakarya River Basin for the 2003-2011 period are given in Table 4, and the estimated average annual distribution of water budget components of the Sakarya River Basin is illustrated in Figure 11.

Table 4. Precipitation data and estimated annual water budget components of the Sakarya River Basin.

\begin{tabular}{lcccccccccc}
\hline Water Budget $\left(\mathbf{k m}^{\mathbf{3}}\right)$ & $\mathbf{2 0 0 3}$ & $\mathbf{2 0 0 4}$ & $\mathbf{2 0 0 5}$ & $\mathbf{2 0 0 6}$ & $\mathbf{2 0 0 7}$ & $\mathbf{2 0 0 8}$ & $\mathbf{2 0 0 9}$ & $\mathbf{2 0 1 0}$ & $\mathbf{2 0 1 1}$ & Average \\
\hline Precipitation & 32.3 & 30.9 & 28.3 & 26.6 & 22.4 & 34.4 & 32.4 & 33.5 & 37.2 & 30.9 \\
Evaporation & 10.6 & 11.5 & 10.8 & 9.8 & 7.7 & 12.2 & 12.4 & 13.7 & 10.8 & 11.1 \\
Transpiration & 11.3 & 13.3 & 11.5 & 11.1 & 10.6 & 12.1 & 10.7 & 12.3 & 14.7 & 12.0 \\
Surface Runoff & 5.0 & 4.7 & 4.4 & 4.1 & 4.0 & 5.0 & 4.9 & 5.2 & 5.4 & 4.7 \\
Flow to Groundwater & 4.3 & 2.0 & 2.0 & 1.7 & 0.2 & 4.5 & 3.9 & 2.2 & 6.8 & 3.1 \\
\hline
\end{tabular}




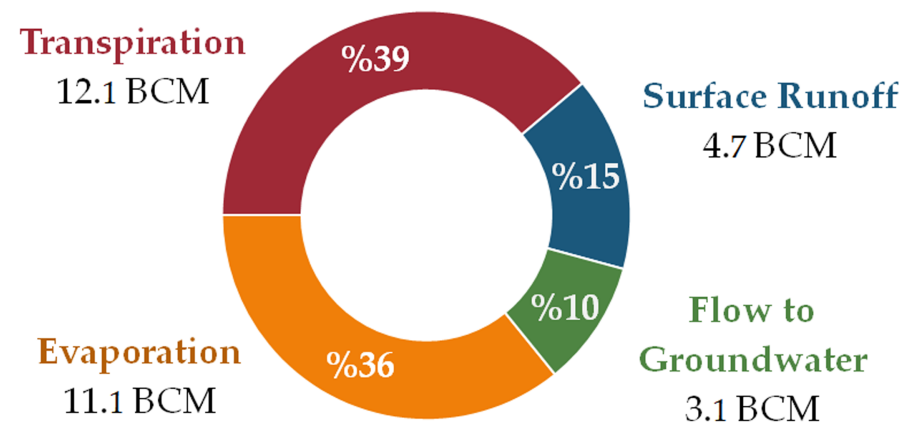

Figure 11. Estimated average water budget components of the Sakarya River Basin.

The long-term annual water budget model results were compared with Turkish State Hydraulic Works (TSHW) data for surface runoff, evapotranspiration, and flow to groundwater. These results are summarized in Table 5. The model estimated lower values for surface runoff, and evapotranspiration; on the other hand, model estimations of flow to groundwater are higher than the TSHW values. The model results estimated that, runoff is 4747 million $\mathrm{m}^{3}$, flow to groundwater is 3065 million $\mathrm{m}^{3}$ and evapotranspiration is 23,011 million $\mathrm{m}^{3}$.

Table 5. Long-term average annual water budget values.

\begin{tabular}{lccc}
\hline Water Budget $\left(\mathbf{m i l .} \mathbf{~ m}^{\mathbf{3}}\right)$ & Surface Runoff & Evapotranspiration & Flow to Groundwater \\
\hline Observed & 6400 & 27,187 & 2197 \\
Simulated & 4747 & 23,011 & 3065 \\
\hline
\end{tabular}

\section{Conclusions}

In this study, the WEAP-PGM model was applied to the Sakarya River Basin in Turkey, where about almost $50 \%$ of the study area is agricultural land. The PGM method was added to the WEAP model in 2015 and is being updated with new versions, so this study is among the first studies in the world and in Turkey to use the model after its release. Compilation and integration of available data from different sources in a data-scarce region and estimation of water budget components of the Sakarya River Basin on an annual basis by using the WEAP model were achieved. Hydrological results were compared with the measurement data and model performance was evaluated by using globally recommended indices in the literature. Model performance indices were found to be within the acceptable ranges according to the literature, considering the objectives of the study. However, there is room to improve the model performance by using more detailed water management data (such as reservoir operations, water demands, etc.) in the basin. The WEAP-PGM model is capable of not only hydrological calculations, but also estimating crop yield in the agricultural activities. This model setup can be used as a baseline for calculating the crop yields under climate change in the context of water-food-energy nexus in the further studies.

Author Contributions: Data curation and Investigation, S.Y.; Methodology and Validation G.C.; Supervision, A.E.; Writing-original draft, S.Y. and G.C.; Writing-review \& editing, A.E.

Funding: This research received no external funding.

Acknowledgments: Authors would like to acknowledge Ali Erturk for his valuable suggestions in the model set-up.

Conflicts of Interest: The authors declare no conflict of interest. 


\section{References}

1. Vörösmarty, C.J.; Green, P.; Salisbury, J.; Lammers, R.B. Global Water Resources: Vulnerability from Climate Change and Population Growth. Sci. New Ser. 2000, 289, 284-288. [CrossRef]

2. Carr, M. New Patterns: Process and Change in Human Geography, 2nd ed.; Nelson Thornes Ltd.: Cheltenham, UK, 1998; ISBN 978-0-17-438681-0.

3. van Dam, J. (Ed.) Impacts of Climate Change and Climate Variability on Hydrological Regimes; Cambridge University Press: Cambridge, UK, 1999; ISBN 978-0-511-56449-9.

4. Refsgaard, J.C.; Abbott, M.B. Distributed Hydrological Modelling; Kluwer Academic: Dordrecht, The Netherlands, 1996; ISBN 978-94-010-6599-3.

5. Singh, V.P.; Woolhiser, D.A. Mathematical Modeling of Watershed Hydrology. J. Hydrol. Eng. 2002, 7, $270-292$. [CrossRef]

6. Grayson, R.B.; Moore, I.D.; McMahon, T.A. Physically based hydrologic modeling: 2. Is the concept realistic? Water Resour. Res. 1992, 28, 2659-2666. [CrossRef]

7. Wurbs, R.A. Dissemination of Generalized Water Resources Models in the United States. Water Int. 1998, 23, 190-198. [CrossRef]

8. Hickey, J.T.; Diaz, G.E. From Flow to Fish to Dollars: An Integrated Approach to Water Allocation. J. Am. Water Resour. Assoc. 1999, 35, 1053-1067. [CrossRef]

9. Singh, V.P.; Frevert, D.K. Watershed Models; Taylor \& Francis: Boca Raton, FL, USA, 2006; ISBN 978-0-8493-3609-6.

10. Yates, D.; Purkey, D.; Sieber, J.; Huber-Lee, A.; Galbraith, H. WEAP21, A Demand, Priority, and Preference-Driven Water Planning Model: Part 2: Aiding Freshwater Ecosystem Service Evaluation. Water Int. 2005, 30, 501-512. [CrossRef]

11. Cuceloglu, G. Darlık Havzasi'nin Model Destekli Hidrolojik Analizi/Model Supported Hydrological Analysis of Darlı Watershed; MSc, Istanbul Technical University: İstanbul, Turkey, 2013.

12. Cuceloglu, G.; Ertürk, A. Model Supported Hydrological Analysis of Darlik Creek Watershed, Istanbul Turkey. Fresenius Environ. Bull. 2014, 23, 3110-3116.

13. Esteve, P.; Varela-Ortega, C.; Blanco-Gutiérrez, I.; Downing, T.E. A Hydro-Economic Model for the Assessment of Climate Change Impacts and Adaptation in Irrigated Agriculture. Ecol. Econ. 2015, 120, 49-58. [CrossRef]

14. Yilmaz, B.; Harmancioglu, N.B. An Indicator Based Assessment for Water Resources Management in Gediz River Basin, Turkey. Water Resour. Manag. 2010, 24, 4359-4379. [CrossRef]

15. Yilmaz, B. Assessing Climate Change Impacts on Gediz Basin Water Balance with WEAP Model. J. Multidiscip. Eng. Sci. Technol. 2015, 2, 3017-3020.

16. Agarwal, S. WEAP-MABIA Model Application in Ur River Watershed in Tikamgarh District, Bundelkhand Region; Central University of Jharkhand: Jharkhand, India, 2018.

17. Agarwal, S.; Patil, J.P.; Goyal, V.C.; Singh, A. Assessment of Water Supply-Demand Using Water Evaluation and Planning (WEAP) Model for Ur River Watershed, Madhya Pradesh, India. J. Inst. Eng. 2018. [CrossRef]

18. Yaykiran, S. Sakarya Havzası'nın Yüksek Çözünürlüklü Hidrolojik Modelinin Yapılandırılması/Structuring the High Resolution Hydrological Model of Sakarya Basin; MSc, Istanbul Technical University: İstanbul, Turkey, 2016.

19. Arnold, J.G.; Srinivasan, R.; Muttiah, R.S.; Williams, J.R. Large Area Hydrologic Modeling and Assessment Part I: Model Development. J. Am. Water Resour. Assoc. 1998, 34, 73-89. [CrossRef]

20. Neitsch, S.L.; Arnold, J.G.; Kiniry, J.R.; Williams, J. Soil and Water Assessment Tool Theoretical Documentation; Version 2009; Texas A\&M University: College Station, TX, USA, 2011.

21. Demirel, M.C.; Venancio, A.; Kahya, E. Flow forecast by SWAT model and ANN in Pracana basin, Portugal. Adv. Eng. Softw. 2009, 40, 467-473. [CrossRef]

22. Güngör, Ö.; Göncü, S. Application of the soil and water assessment tool model on the Lower Porsuk Stream Watershed. Hydrol. Process. 2013, 27, 453-466. [CrossRef]

23. Ertürk, A.; Ekdal, A.; Gürel, M.; Karakaya, N.; Guzel, C.; Gönenç, E. Evaluating the impact of climate change on groundwater resources in a small Mediterranean watershed. Sci. Total Environ. 2014, 499, 437-447. [CrossRef] [PubMed]

24. Golmohammadi, G.; Prasher, S.; Madani, A.; Rudra, R. Evaluating Three Hydrological Distributed Watershed Models: MIKE-SHE, APEX, SWAT. Hydrology 2014, 1, 20-39. [CrossRef] 
25. Santikayasa, I.P. Development of an Integrated Agricultural Planning Model Considering Climate Change. IOP Conf. Ser. Earth Environ. Sci. 2016, 31, 012042. [CrossRef]

26. Emam, A.R.; Kappas, M.; Linh, N.; Renchin, T. Hydrological Modeling and Runoff Mitigation in an Ungauged Basin of Central Vietnam Using SWAT Model. Hydrology 2017, 4, 16. [CrossRef]

27. Cuceloglu, G.; Abbaspour, K.; Ozturk, I. Assessing the Water-Resources Potential of Istanbul by Using a Soil and Water Assessment Tool (SWAT) Hydrological Model. Water 2017, 9, 814. [CrossRef]

28. Vaghefi, S.A.; Abbaspour, K.; Faramarzi, M.; Srinivasan, R.; Arnold, J. Modeling Crop Water Productivity Using a Coupled SWAT-MODSIM Model. Water 2017, 9, 157. [CrossRef]

29. Duru, U.; Arabi, M.; Wohl, E.E. Modeling stream flow and sediment yield using the SWAT model: A case study of Ankara River basin, Turkey. Phys. Geogr. 2018, 39, 264-289. [CrossRef]

30. Panagopoulos, Y.; Gassman, P.W.; Jha, M.K.; Kling, C.L.; Campbell, T.; Srinivasan, R.; White, M.; Arnold, J.G. A refined regional modeling approach for the Corn Belt-Experiences and recommendations for large-scale integrated modeling. J. Hydrol. 2015, 524, 348-366. [CrossRef]

31. Lindström, G.; Johansson, B.; Persson, M.; Gardelin, M.; Bergström, S. Development and test of the distributed HBV-96 hydrological model. J. Hydrol. 1997, 201, 272-288. [CrossRef]

32. Lindström, G.; Pers, C.; Rosberg, J.; Strömqvist, J.; Arheimer, B. Development and testing of the HYPE (Hydrological Predictions for the Environment) water quality model for different spatial scales. Hydrol. Res. 2010, 41, 295-319. [CrossRef]

33. Pechlivanidis, I.G.; Arheimer, B. Large-scale hydrological modelling by using modified PUB recommendations: The India-HYPE case. Hydrol. Earth Syst. Sci. 2015, 19, 4559-4579. [CrossRef]

34. Donnelly, C.; Andersson, J.C.M.; Arheimer, B. Using flow signatures and catchment similarities to evaluate the E-HYPE multi-basin model across Europe. Hydrol. Sci. J. 2016, 61, 255-273. [CrossRef]

35. Donnelly, C.; Arheimer, B.; Capell, R.; Dahné, J.; Strömqvist, J. Regional overview of nutrient load in Europe - challenges when using a large-scale model approach, E-HYPE. IAHS Publ. 2013, 361, 49-58.

36. Arheimer, B.; Dahné, J.; Donnelly, C.; Lindström, G.; Strömqvist, J. Water and Nutrient Simulations Using the HYPE model for Sweden vs. the Baltic Sea Basin - Influence of Input-Data Quality and Scale. Hydrol. Res. 2012, 43, 315-329. [CrossRef]

37. Yin, Y.; Jiang, S.; Pers, C.; Yang, X.; Liu, Q.; Yuan, J.; Yao, M.; He, Y.; Luo, X.; Zheng, Z. Assessment of the Spatial and Temporal Variations of Water Quality for Agricultural Lands with Crop Rotation in China by Using a HYPE Model. Int. J. Environ. Res. Public Health 2016, 13, 336. [CrossRef]

38. Singh, V.P. MIKE SHE (Chapter 23). In Computer Models of Watershed Hydrology; Water Resources Publications: Highlands Ranch, CO, USA, 1995; p. 1130. ISBN 978-0-918334-91-6.

39. Butts, M.; Graham, D. Flexible Integrated Watershed Modeling with MIKE SHE. In Watershed Models; Frevert, D., Singh, V., Eds.; CRC Press: Boca Raton, FL, USA, 2005; pp. 245-271. ISBN 978-0-8493-3609-6.

40. Keilholz, P.; Disse, M.; Halik, Ü. Effects of Land Use and Climate Change on Groundwater and Ecosystems at the Middle Reaches of the Tarim River Using the MIKE SHE Integrated Hydrological Model. Water 2015, 7, 3040-3056. [CrossRef]

41. U.S. Army Corps of Engineers. HEC-HMS Technical Reference Manual; U.S. Army Corps of Engineers: Washington, DC, USA, 2000.

42. Zelelew, D.; Melesse, A. Applicability of a Spatially Semi-Distributed Hydrological Model for Watershed Scale Runoff Estimation in Northwest Ethiopia. Water 2018, 10, 923. [CrossRef]

43. Koneti, S.; Sunkara, S.; Roy, P. Hydrological Modeling with Respect to Impact of Land-Use and Land-Cover Change on the Runoff Dynamics in Godavari River Basin Using the HEC-HMS Model. ISPRS Int. J. Geo-Inf. 2018, 7, 206. [CrossRef]

44. Chen, T.; Ren, L.; Yuan, F.; Yang, X.; Jiang, S.; Tang, T.; Liu, Y.; Zhao, C.; Zhang, L. Comparison of Spatial Interpolation Schemes for Rainfall Data and Application in Hydrological Modeling. Water 2017, 9, 342. [CrossRef]

45. Srinivasan, R.; Krysanova, V.; Wechsung, F.; Arnold, J.; Williams, J. SWIM (Soil and Water Integrated Model) User Manual; PIK Reports Potsdam Institute for Climate Impact Research: Houston, TX, USA, 2000.

46. Hattermann, F.F.; Wattenbach, M.; Krysanova, V.; Wechsung, F. Runoff simulations on the macroscale with the ecohydrological model SWIM in the Elbe catchment-validation and uncertainty analysis. Hydrol. Process. 2005, 19, 693-714. [CrossRef] 
47. Krysanova, V.; Müller-Wohlfeil, D.-I.; Becker, A. Development and test of a spatially distributed hydrological/water quality model for mesoscale watersheds. Ecol. Model. 1998, 106, 261-289. [CrossRef]

48. Lobanova, A.; Stagl, J.; Vetter, T.; Hattermann, F. Discharge Alterations of the Mures River, Romania under Ensembles of Future Climate Projections and Sequential Threats to Aquatic Ecosystem by the End of the Century. Water 2015, 7, 2753-2770. [CrossRef]

49. Didovets, I.; Lobanova, A.; Bronstert, A.; Snizhko, S.; Maule, C.; Krysanova, V. Assessment of Climate Change Impacts on Water Resources in Three Representative Ukrainian Catchments Using Eco-Hydrological Modelling. Water 2017, 9, 204. [CrossRef]

50. Donigian, A.S.; Imhoff, J.C.; Bicknell, B.R.; Kittle, J.L.; Nichols, A. Application Guide for Hydrological Simulation Program Fortran (HSPF); U.S. Environmental Protection Agency: Athens, Greece, 1984.

51. Kim, Y.-J.; Kim, H.-D.; Jeon, J.-H. Characteristics of Water Budget Components in Paddy Rice Field under the Asian Monsoon Climate: Application of HSPF-Paddy Model. Water 2014, 6, 2041-2055. [CrossRef]

52. Ahmed, S.I.; Singh, A.; Rudra, R.; Gharabaghi, B. Comparison of CANWET and HSPF for water budget and water quality modeling in rural Ontario. Water Qual. Res. J. Can. 2014, 49, 53-71. [CrossRef]

53. Yan, C.-A.; Zhang, W.; Zhang, Z. Hydrological Modeling of the Jiaoyi Watershed (China) Using HSPF Model. Sci. World J. 2014, 2014, 1-9. [CrossRef]

54. Strömbäck, L.; Arheimer, B.; Lindström, G.; Donnelly, C.; Gustafsson, D. The Importance of Open Data and Software for Large Scale Hydrological Modelling. Open Water J. 2013, 2, 7.

55. Ekeu-wei, I.T.; Blackburn, G.A. Applications of Open-Access Remotely Sensed Data for Flood Modelling and Mapping in Developing Regions. Hydrology 2018, 5, 39. [CrossRef]

56. Sevastas, S.; Siarkos, I.; Theodossiou, N.; Ifadis, I.; Kaffas, K. Comparing hydrological models built upon open access and/or measured data in a GIS environment. In Proceedings of the Water Resources Engineering and Management, Thessaloniki, Greece, 25-30 June 2017; pp. 377-386.

57. Falkenmark, M. The Massive Water Scarcity Now Threatening Africa: Why Isn't It Being Addressed? Ambio 1989, 18, 112-118.

58. Ceribasi, G.; Dogan, E. Trend Analysis of Average Annual Precipitation for Black Sea and Sakarya Basin. Suleyman Demirel Univ. Int. J. Technol. Sci. 2015, 7, 1-7.

59. Karşili, C. Türkiye'de Akarsu Havzalarında Kişi Başına Düşen Su Miktarının Coğrafi Bilgi Sistemleriyle Analizi; MSc, Ankara Üniversitesi: Ankara, Turkey, 2011.

60. Republic of Turkey the Ministry of Forestry and Water Affairs General Directorate of Water Management. Climate Change Impacts On Water Resources Project, Final Report-Executive Summary; Republic of Turkey the Ministry of Forestry and Water Affairs General Directorate of Water Management: Ankara, Turkey, 2016.

61. Moroglu, M.; Yazgan, M.S. Implementation of EU Water Framework Directive in Turkey. Desalination 2008, 226, 271-278. [CrossRef]

62. Göl, C.; Yilmaz, H. Legal and Administrative Problems in Watershed Management in Turkey: Case of Tatlicay Watershed. Environ. Eng. Manag. J. 2017, 16, 2685-2698.

63. Sieber, J.; Purkey, D. WEAP Plant Growth Model Technical Documentation; Stockholm Environment Institute: Stockholm, Sweden, 2015.

64. Sieber, J.; Purkey, D. Water Evaluation and Planning System (WEAP) User Guide; Stockholm Environment Institute U.S. Center: Somerville, MA, USA, 2015.

65. Arnold, J.G.; Moriasi, D.N.; Gassman, P.W.; Abbaspour, K.C.; White, M.J.; Srinivasan, R.; Santhi, C.; Harmel, R.D.; van Griensven, A.; van Liew, M.W.; et al. SWAT: Model Use, Calibration, and Validation. Trans. ASABE 2012, 55, 1491-1508. [CrossRef]

66. Williams, J.R.; Renard, K.G.; Dyke, P.T. EPIC, a new model for assessing erosion's effect on soil productivity. J. Soil Water Conserv. 1984, 38, 381-383.

67. Stockle, C.O.; Williams, J.R.; Rosenberg, N.J. A Method for Estimating the Direct and Climatic Effects of Rising Atmospheric Carbon Dioxide on Growth and Yield of Crops: Part I-Modification of the EPIC Model for Climate Change Analysis. Agric. Syst. 1991, 38, 225-238. [CrossRef]

68. Stockle, C.O.; Dyke, P.T.; Williams, J.R.; Jones, C.A.; Rosenberg, N.J. A method for estimating the direct and climatic effects of rising atmospheric carbon dioxide on growth and yield of crops: Part II-Sensitivity analysis at three sites in the Midwestern USA. Agric. Syst. 1992, 38, 239-256. [CrossRef]

69. Steduto, P.; Raes, D.; Hsiao, T.C.; Fereres, E.; Heng, L.; Izzi, G.; Hoogeveen, J. AquaCrop: A New Model for Crop Prediction Under Water Deficit Conditions. Options Méditerr. 2009, 285-292. 
70. TUBITAK The Scientific and Technological Research Council of Turkey. Watershed Protection Action Plan for Sakarya Basin, Final Report; TUBITAK: İstanbul, Turkey, 2013.

71. Isik, S.; Singh, V.P. Assessment of the watershed yield of the Sakarya River basin, Turkey. IAHS 2007, 313, 338-345.

72. Bayazit, M. Systems approach to management of the Sakarya River Basin. Int. J. Water Resour. Dev. 1983, 1, 323-330. [CrossRef]

73. NASA (National Aeronautics and Space Administration) SRTM 90 m DEM Digital Elevation Database. Available online: http:/ / srtm.csi.cgiar.org/ (accessed on 15 January 2016).

74. EPA (European Environment Agency) CORINE (Coordination of Information on the Environment) 2012 Land Cover Project. Available online: https://land.copernicus.eu/pan-european/corine-land-cover/clc-2012 (accessed on 8 February 2016).

75. Former Ministry of Food, Agriculture and Livestock of the Republic of Turkey Turkish National Soil Database. Ankara, Turkey. Available online: https:/ / en.wikipedia.org/wiki/Ministry_of_Food,_Agriculture_and_ Livestock_(Turkey) (accessed on 3 February 2019).

76. ISRIC (International Soil Reference and Information Centre) Soil Grid $1 \mathrm{~km}$ Project. Available online: http:/ / soilgrids1km.isric.org/ (accessed on 24 February 2016).

77. TSI (Turkish Statistics Institute) Crop Production Statistics Database. Available online: https://biruni.tuik. gov.tr/bitkiselapp/bitkisel.zul (accessed on 1 March 2016).

78. Former Ministry of Forestry and Water of the Republic of Turkey Affairs Stand Type Map Database. Ankara, Turkey. Available online: https:/ /www.afad.gov.tr/upload/Node/3484/xfiles/seismic_microzonation_ manual_eng.pdf (accessed on 3 February 2019).

79. Turkish National Climate Reports; TSMS (Turkish State Meteorological Service): Ankara, Turkey, 2016.

80. TSHW (Turkish State Hydraulic Works) Turkish National River Discharges Reports. Ankara, Turkey. Available online: http:/ / en.dsi.gov.tr/ (accessed on 3 February 2019).

81. Luzio, M.D.; Srinivasan, R.; Arnold, J.G.; Neitsch, S.L. ArcView Interface for SWAT2000; Texas A\&M University System: College Station, TX, USA, 2002.

82. Winchell, M.; Srinivasan, R.; Di Luzio, J. ARCSWAT Interface for SWAT2009-User's Guide; Blackland Research Center; Texas Agricultural Experiment Station: Temple, TX, USA, 2010; Volume 489.

83. Genuchten, M.T.V. A Closed-form Equation for Predicting the Hydraulic Conductivity of Unsaturated Soils. Soil Sci. Soc. Am. J. 1980, 44, 892-898. [CrossRef]

84. Nash, J.E.; Sutcliffe, J.V. River flow forecasting through conceptual models part I A discussion of principles. J. Hydrol. 1970, 10, 282-290. [CrossRef]

85. Gupta, H.V.; Kling, H.; Yilmaz, K.K.; Martinez, G.F. Decomposition of the mean squared error and NSE performance criteria: Implications for improving hydrological modelling. J. Hydrol. 2009, 377, 80-91. [CrossRef]

86. Bennett, N.D.; Croke, B.F.W.; Guariso, G.; Guillaume, J.H.A.; Hamilton, S.H.; Jakeman, A.J.; Marsili-Libelli, S.; Newham, L.T.H.; Norton, J.P.; Perrin, C.; et al. Characterising performance of environmental models. Environ. Model. Softw. 2013, 40,1-20. [CrossRef]

87. Kling, H.; Fuchs, M.; Paulin, M. Runoff conditions in the upper Danube basin under an ensemble of climate change scenarios. J. Hydrol. 2012, 424-425, 264-277. [CrossRef]

88. Daggupati, D.N.M.; Gitau, M.W.; Pai, N. Hydrologic and Water Quality Models: Performance Measures and Evaluation Criteria. Trans. ASABE 2015, 58, 1763-1785.

89. Moriasi, D.N.; Arnold, J.G.; Liew, M.W.V.; Bingner, R.L.; Harmel, R.D.; Veith, T.L. Model Evaluation Guidelines for Systematic Quantification of Accuracy in Watershed Simulations. Trans. ASABE 2007, 50, 885-900. [CrossRef]

90. Siddiqui, M.A.R. Lag and Attenuation Parameters for Routing Daily Flow Changes Through Large River Systems; MSc, Texas A\&M University: College Station, TX, USA, 2017.

91. Granato, G.E. Estimating Basin Lagtime and Hydrograph-Timing Indexes Used to Characterize Stormflows; Scientific Investigations Report 2012-5110; U.S. Geological Survey: Reston, VA, USA, 2012; p. 58.

(C) 2019 by the authors. Licensee MDPI, Basel, Switzerland. This article is an open access article distributed under the terms and conditions of the Creative Commons Attribution (CC BY) license (http:/ / creativecommons.org/licenses/by/4.0/). 